\title{
Suitability of Scoria as Fine Aggregate and Its Effect on the Properties of Concrete
}

\author{
Getachew Kebede Warati ${ }^{1, *}$, Muge Mukaddes Darwish ${ }^{2}$, Fekadu Fufa Feyessa ${ }^{3}{ }^{(1)}$ and \\ Tewodros Ghebrab ${ }^{2}$ \\ 1 Civil Engineering department, Jimma University Institute of Technology, Jimma-Ethiopia, \\ P.O. Box 378, Ethiopia \\ 2 Civil, Environmental, and Construction Engineering, Texas Tech University, Lubbock, TX 79409-1023, USA \\ 3 Environmental Engineering Department, Jimma University Institute of Technology, Jimma-Ethiopia, P.O. \\ Box 378, Ethiopia \\ * Correspondence: getchitaly@yahoo.com
}

Received: 29 July 2019; Accepted: 22 August 2019; Published: 26 August 2019

check for updates

\begin{abstract}
The increase in the demand for concrete production for the development of infrastructures in developing countries like Ethiopia leads to the depletion of virgin aggregates and high cement demand, which imposes negative environmental impacts. In sustainable development, there is a need for construction materials to focus on the economy, efficient energy utilization, and environmental protections. One of the strategies in green concrete production is the use of locally available construction materials. Scoria is widely available around the central towns of Ethiopia, especially around the rift valley regions where huge construction activities are taking place. The aim of this paper is therefore to analyze the suitability of scoria as a fine aggregate for concrete production and its effect on the properties of concrete. A differing ratio of scoria was considered as a partial replacement of fine aggregate with river sand after analyzing its engineering properties, and its effect on the mechanical properties of concrete were examined. The test results on the engineering properties of scoria revealed that the material is suitable to be used as a fine aggregate in concrete production. The replacement of scoria with river sand also enhanced the mechanical strength of the concrete. Generally, the findings of the experimental study showed that scoria could replace river sand by up to $50 \%$ for conventional concrete production.
\end{abstract}

Keywords: green concrete; scoria; river sand; virgin aggregate; sustainable development

\section{Introduction}

Concrete is one of the most widely used construction materials in the construction industry of Ethiopia, like other countries of the world. The production of concrete-making materials or ingredients usually needs high energy, costs, and causes environmental pollution. Green concrete is characterized by the application of industrial by-products or alternative materials for wise utilization of natural resources and to save energy besides minimizing environmental pollution [1].

The increase in the demand for concrete production leads to the depletion of virgin concrete ingredients, which is a critical issue for all stakeholders of the construction industry for sustainable economic growth, particularly in developing countries. Therefore, there is a need to provide further attention to construction materials with regards to the economy, wise energy utilization, and environmental protection for sustainable development [2]. Fine aggregate is one of the ingredients of concrete that needs to get considerable attention in the production of green concrete, and it usually comprises up to $30 \%$ to $35 \%$ of the total volume of concrete. Natural or river sand is the most commonly used fine aggregate in the production of concrete. 
The construction industry exploits sand mainly from stream beds, sandy marine sediments, and alluvial deposits [3]. Currently, a shortage of natural or river sand has become a problem for the construction industry in Ethiopia as a result of growing construction activities in many parts of the country, leading to significant depletion of natural sand $[4,5]$. The primary source of sand that is provided to construction worksites of the nearby towns of Addis Ababa city is Awash basin, located at a distance of about 70 to $120 \mathrm{~km}$ from Addis Ababa. The supply of river sand from such a long distance makes the production and supply of sand energy-intensive and costly. Moreover, the quality of the sand supplied from this source is poor with regards to its silt content, which is sometimes as high as $20 \%$, going far beyond the standard limit [6].

The quality of constituent materials used in the production of concrete plays a principal role in determining the physical as well as the strength properties of the resultant concrete [7]. The properties of sand, specifically the gradation and fineness modulus of sand, are among the principal factors known to affect the performance of both fresh and hardened concrete [8,9]. Impurities, such as organic matter, silt, and clay content, in the sand contribute to a reduction in the compressive strength of the concrete. Olanitori [10] revealed that the compressive strength of hardened concrete decreases as the percentage of the silt and clay contents increases. Thus, assessing the quality of construction materials is very important to build strong, durable, and cost-effective structures for sustainable infrastructure development [11].

In order to minimize environmental degradation in the depletion of natural sand, and the associated cost of transportation, the use of locally available alternative materials is a critical solution. The use of locally available construction materials that are suitable for concrete production is recommended for the improvement of concrete performance at a comparable environmental incidence and lifetime [12].

Quarry dust wastes are used as alternative construction materials for natural sand replacement in order to minimize the shortage of river sand in concrete production in some countries. For instance, quarry dust was used to replace the river sand in India to conserve the sustainable development of scarcely available natural sand [13,14]. Quarry wastes are also used as a partial replacement for natural sand in the production of concrete in Malaysia [15]. Some alternative materials, such as fly ash, copper slag, limestone, and siliceous stone powder, are also used as a partial or full replacement of river sand in the production of mortar and concrete [16]. The strength and durability properties of concrete containing copper slag as a fine aggregate have been evaluated and an improvement has been observed up to a replacement level of $40 \%$ as investigated by [17]. Another research was done in the use of ferronickel slag as fine aggregate in which the workability and compressive strength properties of mortar were enhanced up to a 50\% replacement for river sand [18].

Scoria, which is a product of explosive volcanic eruptions, has been used for centuries in the world as a construction material. Different researchers have examined the use of scoria as a construction material in concrete production. According to [19], scoria used as a coarse aggregate was found to be very useful in the production of lightweight concrete, with sufficient strength giving it the advantage of reducing the dead load in building structures. Scoria is also used as a lightweight aggregate with silica fume and fly ash mineral admixture in the production of lightweight structural concrete in which an outstanding performance was observed with regards to the strength to unit weight ratio [20]. Improvements in the mechanical strength of mortar were also observed when using volcanic scoria as sand in the production of Portland cement mortar [21].

Volcanic materials are comprehensively utilized in the production of blended cement due to their availability and properties. Volcanic materials are used as supplementary cementitious materials to produce environmentally friendly concrete [22]. The use of scoria as a replacement of cement was investigated in the production of self-consolidating concrete, which was found to be economically and environmentally pleasant with the required strength and durability properties of concrete [23]. The use of scoria as a replacement of cement in concrete production also improved the durability of the concrete by increasing its resistance to chloride penetration and giving longer periods of corrosion 
initiation [24]. Scoria, as a cement additive in Portland cement, was found to be effective in improving the property of the cement paste, particularly in controlling the alkali-silica reaction [25].

Scoria is widely available around Addis Ababa and in the rift valley regions of Ethiopia and thus can be used as an alternative construction material in concrete production [26]. The quarry sites of scoria are limited to the use of sub-base road construction and are found a short distance of about 0.5 to $4.2 \mathrm{~km}$ from the nearby towns, such as Adama, Bishoftu, and Mojo, unlike natural or river sand. Hence, the use of this material as fine aggregate in concrete production helps to save energy and cost $[27,28]$.

The physical and chemical properties of an aggregate are attributed to the parent material. However, the shape, size, and surface texture(s) are essential for the concrete's workability, and bond characteristics between the aggregate and cement paste are attributed to the mode of production. It is essential that the properties of the aggregate and its modes of production are understood to produce the required quality of concrete [6,29].

The aim of this study was to investigate the suitability of scoria as fine aggregate and its effect on the physical and mechanical properties of concrete.

\section{Materials and Methods}

\subsection{Scoria}

The scoria sample was collected from the quarry site indicated in Figure 1 around Adama town, is found in the eastern part of Ethiopia at a geographical location of $8.54^{\circ} \mathrm{N}$ and $39.27^{\circ} \mathrm{E}$ at a distance of $100 \mathrm{~km}$ from Addis Ababa. The grain size distributions of the sample taken directly from the quarry site have the range of fine aggregate. Thus, the physical properties of this sample were determined to check its suitability as a fine aggregate in concrete production.
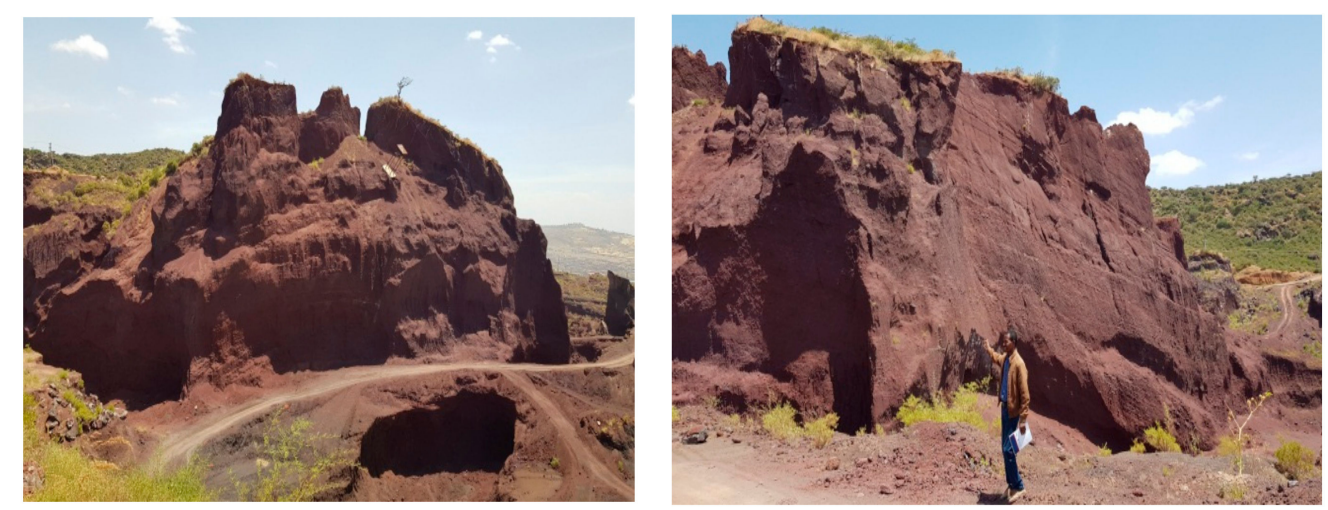

Figure 1. Scoria quarry site near Adama town.

\subsubsection{Gradation}

Sieve analysis was conducted to determine the proportion of the different sizes of aggregates and whether it satisfies the specification requirement in accordance with ASTM C33 and C136 [30,31] for use as a fine aggregate in concrete production. The series of standard sieves of square openings were placed in consecutive sizes in which the largest sieve size was placed at the top and the smallest was at the bottom, followed by a pan. The standard sample size was added to the sieve, allowing for shaking by the machine for 15 minutes. From the particle size distribution of the aggregate, the fineness modulus of the material was also determined to identify the coarseness or fineness of the material. As per the ASTM C33 specification [30], the fineness of fine aggregate needs to be in the range of 2.3 to 3.1. Based on the fineness modulus of fine aggregate, sand can be categorized as fine sand (2.2 to 2.6), medium sand (2.6 to 2.9), or coarse sand (2.9 to 3.2) as per the Ethiopian standard specification of building and road materials [32]. 
A blending of aggregates is undertaken when there is a deficiency in the grading of an aggregate. If two aggregates, designated $A$ and $B$, are mixed together, with a fineness modulus of $\mathrm{FM}_{A}$ and $\mathrm{FM}_{\mathrm{B}}$, the resultant blend fineness is calculated using a formula [33].

The results of the sieve analysis of the scoria sample taken from the quarry site of the study area are shown in Table 1. As it is shown in Table 1 and Figure 2, the cumulative percentage passes required for sieve sizes of 2.36, 0.6, and $0.3 \mathrm{~mm}$ are out of the ASTM C33 standard limit [30]. Thus, the particle size distribution of scoria does not fulfill the required specification of the standard and needs blending for use in concrete production.

Table 1. Percentage passes of scoria fine aggregates.

\begin{tabular}{ccc}
\hline Sieve Sizes & Cum. \% Passed Scoria & $\begin{array}{c}\text { Percentage Passing } \\
\text { (ASTM C33 Standard) }\end{array}$ \\
\hline $9.75 \mathrm{~mm}$ & 100 & 100 \\
$4.75 \mathrm{~mm}$ & 95.30 & $95-100$ \\
$2.36 \mathrm{~mm}$ & 75.40 & $80-100$ \\
$1.18 \mathrm{~mm}$ & 55.30 & $50-85$ \\
$0.6 \mathrm{~mm}$ & 19.15 & $25-60$ \\
$0.3 \mathrm{~mm}$ & 5.20 & $10-30$ \\
$0.15 \mathrm{~mm}$ & 2.05 & $2-10$ \\
\hline
\end{tabular}

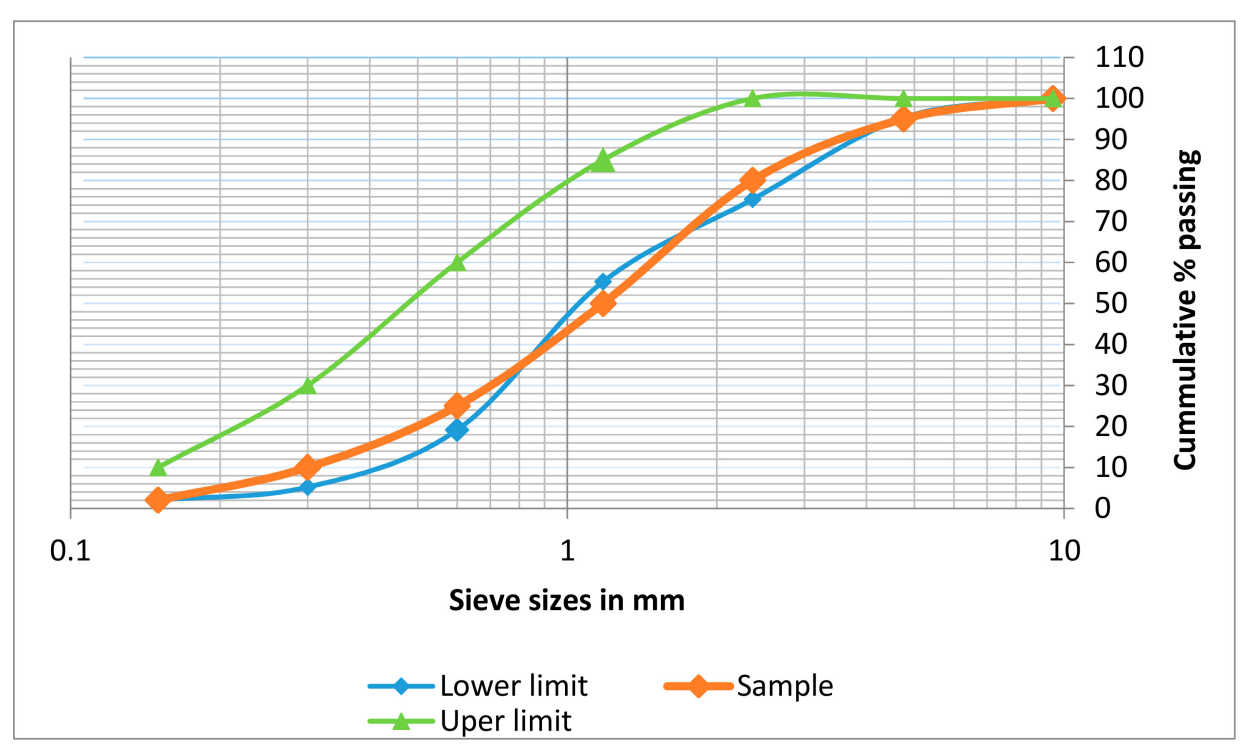

Figure 2. Scoria aggregate sieve analysis graphical representation.

\subsubsection{Fineness Modulus}

The percentages retained on the sieve sizes are indicated in Table 2, from which the fineness modulus of the scoria sample was determined. The fineness modulus (FM) of fine aggregate generally needs to lie between 2.3 and 3.1 as per the ASTM C136 specification as already mentioned. However, the FM of the scoria sample, which is 3.47 , is out of the range of the limit set by the standard and thus should not be used without blending. Since the scoria sample is a coarser fine aggregate, it has to be blended with fine aggregate or sand with smaller fineness modulus to meet the standard specification after being blended. 
Table 2. Percentage retained of scoria fine aggregates.

\begin{tabular}{ccc}
\hline Sieve Sizes & \% Retained & Cumulative \% Retained \\
\hline $9.75 \mathrm{~mm}$ & 0 & 0 \\
$4.75 \mathrm{~mm}$ & 4.70 & 4.70 \\
$2.36 \mathrm{~mm}$ & 19.90 & 24.60 \\
$1.18 \mathrm{~mm}$ & 20.00 & 44.60 \\
$0.6 \mathrm{~mm}$ & 36.20 & 80.80 \\
$0.3 \mathrm{~mm}$ & 14.00 & 94.80 \\
$0.15 \mathrm{~mm}$ & 3.15 & 97.95 \\
\hline
\end{tabular}

\subsubsection{Silt Content, Specific Gravity, and Water Absorption Capacity}

The material in the fine aggregates that has a smaller size than $75 \mu \mathrm{m}$ is generally regarded as silt. Silt in the fine aggregate can have a severe effect on the quality of the concrete. It mainly affects the workability of the concrete, and also results in a reduction in strength. The silt content of the sample was determined in the laboratory using the ASTM C117 standard specification [34]. According to the standard, the maximum silt content is limited to $3 \%$.

Specific gravity is the ratio between the weight of the substance and that of the same volume of water. In this definition, the substance or material is assumed to be solid. The apparent specific gravity of an aggregate refers to the solid materials excluding the pores, and the bulk specific gravity refers to the total volume, including the pores of the aggregate.

Absorption capacity refers to the amount of water a solid aggregate material can absorb. The maximum water absorption capacity of fine aggregate is limited to only $3 \%$ as per the ASTM C128 specification [35]. Both the specific capacity and water absorption capacity are determined using the Pycnometer method.

The unit weight effectively measures the volume that the graded aggregates occupy in concrete and includes both the solid aggregate particles and the voids between the aggregates. The unit weight of the sample was measured using ASTM C29/29M [36] by filling the sample in a container of a known volume $\left(0.005 \mathrm{~m}^{3}\right)$ and weighing it.

A summary of the physical properties of scoria is shown in Table 3. The result obtained from the laboratory test showed the bulk specific gravity and the apparent specific gravity of the scoria sample was found to be 2.397 and 2.457, respectively. In addition, the water absorption capacity of scoria was found to be very low, with a numerical value of $0.6 \%$. From the experiment conducted, the scoria seems to have a smaller bulk density of $1165.70 \mathrm{~kg} / \mathrm{m}^{3}$ as compared to common river sand. The silt content of the scoria sample was found to be $0.76 \%$, which is less than the ASTM standard [34].

Table 3. Summary of the physical properties of the scoria sample.

\begin{tabular}{cc}
\hline \multicolumn{2}{c}{ Physical Properties of Scoria Fine Aggregate } \\
\hline Silt content $(\%)$ & 0.76 \\
Fineness modulus (FM) & 3.47 \\
Bulk Unit weight $\left(\mathrm{kg} / \mathrm{m}^{3}\right)$ & 1165.70 \\
Bulk Specific gravity & 2.397 \\
Apparent Specific gravity & 2.457 \\
Water absorption capacity (\%) & 0.60 \\
\hline
\end{tabular}

\subsubsection{Chemical Composition of Scoria}

The scoria sample was ground or milled, and the chemical composition of the scoria powder shown in Figure 3 was determined at the Geochemical Laboratory of Geological Survey of Ethiopia. The analytical method of elemental analysis was conducted to determine the mineral composition of the scoria powder, and the obtained result is shown in Table 4. From the result obtained, the scoria powder contains a greater amount of silicon dioxide $(52.53 \%)$, which is followed by aluminate and 
ferrite, with a percentage of $15.49 \%$ and $11.00 \%$, respectively. The summation of these three oxide compositions was found to be $79.02 \%$, and the material is classified as class F pozzolanic material according to ASTM C-618 [37].

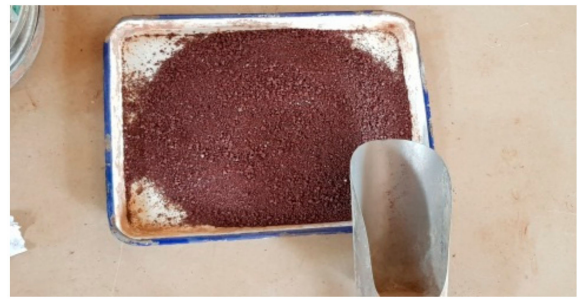

(a)

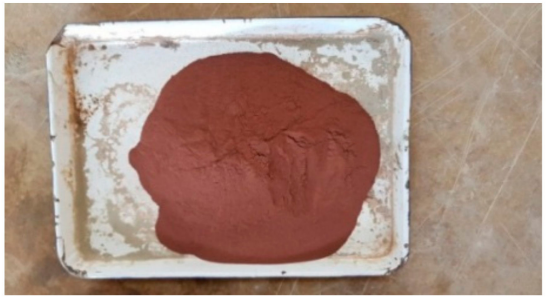

(b)

Figure 3. Picture of scoria sample: (a) Scoria aggregate; (b) Scoria powder.

Table 4. Chemical composition of scoria.

\begin{tabular}{ccccccccccccc}
\hline Composition & $\mathrm{SiO}_{2}$ & $\mathrm{Al}_{2} \mathrm{O}_{3}$ & $\mathrm{Fe}_{2} \mathrm{O}_{3}$ & $\mathrm{CaO}$ & $\mathbf{M g O}$ & $\mathrm{Na}_{2} \mathrm{O}$ & $\mathbf{K}_{2} \mathrm{O}$ & $\mathrm{MnO}$ & $\mathbf{P}_{2} \mathrm{O}_{5}$ & $\mathrm{TiO}_{2}$ & $\mathrm{H}_{2} \mathrm{O}$ & $\mathrm{LOI}$ \\
\hline Content (\%) & 52.53 & 15.49 & 11.0 & 10.1 & 4.4 & 2.56 & $<0.1$ & 0.18 & 0.17 & 0.88 & 0.64 & 0.85 \\
\hline
\end{tabular}

\subsection{Sand}

Natural river sand, which is supplied from the Gambella region in Ethiopia, was used in this study. All the physical properties that were determined for scoria were also determined following the same procedure for use of the sand fully or partially as a fine aggregate in concrete production.

\subsubsection{Gradation and Fineness Modulus}

The particle size distribution of river sand was analyzed, and the obtained result shown in Table 5. The obtained result fulfills the ASTM C33 [30] standard specification for concrete production. The grain size distribution of the river sand used, indicated in Figure 4 shows that it is fine sand since its fineness modulus, which is 2.36 , lies between 2.2 to 2.6 .

Table 5. Gradation of river sand.

\begin{tabular}{cccc}
\hline Sieve Sizes in mm & Cumulative \% Retained & Cumulative \% Passed & $\begin{array}{c}\text { Cumulative \% Pass } \\
\text { (ASTM C33) }\end{array}$ \\
\hline 9.50 & 0 & 100 & 100 \\
4.75 & 0.74 & 99.26 & $95-100$ \\
2.36 & 3.45 & 96.55 & $80-100$ \\
1.18 & 18.23 & 81.77 & $50-85$ \\
0.60 & 48.28 & 51.72 & $25-60$ \\
0.30 & 72.91 & 27.09 & $5-30$ \\
0.15 & 92.61 & 7.39 & $0-10$ \\
0.075 & 99.62 & 0.68 & \\
\hline
\end{tabular}




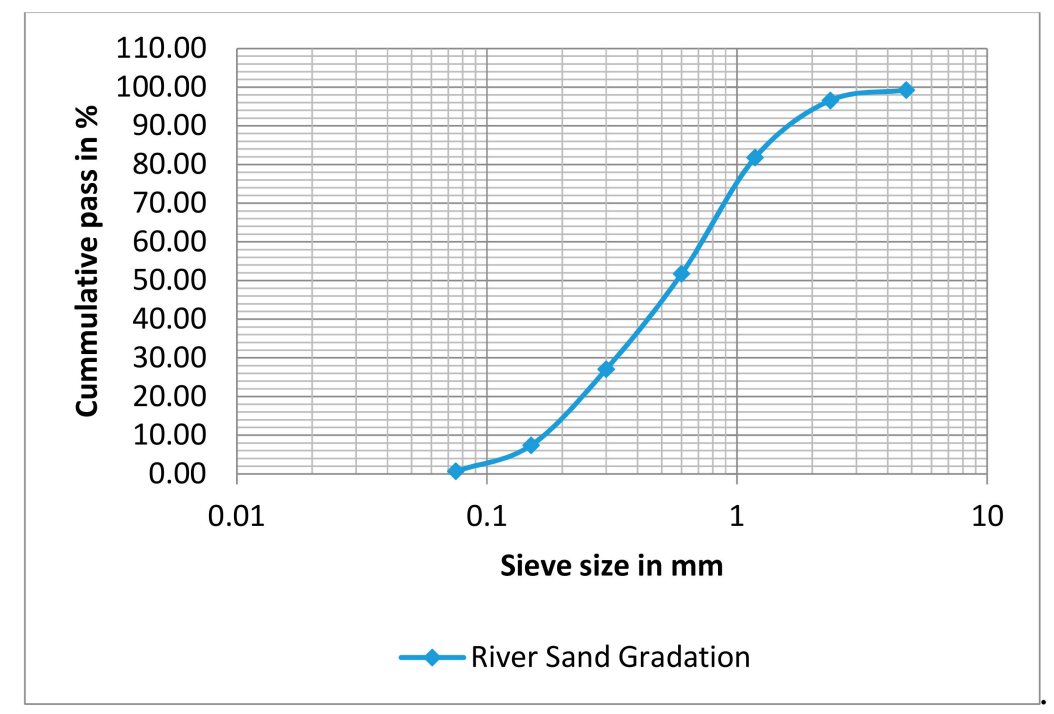

Figure 4. River sand grain size distribution curve.

\subsubsection{Specific Gravity and Water Absorption Capacity}

A summary of the physical properties of the river sand is presented in Table 6 . The bulk specific gravity and apparent specific gravity of river sand were determined to be 2.58 and 2.67, respectively. The silt content test result of the river sand was found to be $4.26 \%$, which is above the maximum allowable limit of the ASTM C117 specification [34]. Therefore, the river sand was washed, and its silt content was reduced to $1.56 \%$ to keep the standard specification for concrete production. The bulk density of the river sand determined from the laboratory result was $1482 \mathrm{~kg} / \mathrm{m}^{3}$. The water absorption capacity of the sand was found to be $0.67 \%$.

Table 6. Summary of the physical properties of the river sample.

\begin{tabular}{cc}
\hline Physical Properties of River Sand Fine Aggregate \\
\hline Silt content (\%) & 1.56 \\
Fineness modulus (FM) & 2.36 \\
Bulk Unit weight $\left(\mathrm{kg} / \mathrm{m}^{3}\right)$ & 1482 \\
Bulk Specific gravity & 2.58 \\
Apparent Specific gravity & 2.67 \\
Water absorption capacity (\%) & 0.67 \\
\hline
\end{tabular}

\subsection{Coarse Aggregate}

The coarse aggregate used in this study was crushed stone gravel of basaltic origin. The maximum nominal size of the coarse aggregate used was $20 \mathrm{~mm}$. Gradation of the coarse aggregate conducted to check whether it fulfilled the ASTM C-33 specification [30] for concrete production. The test result of the grain size distribution of the coarse aggregate is indicated in Figure 5. The unit weight, specific gravity, moisture content, and water absorption of the aggregate were also determined using ASTM C-29, ASTM C-127, and ASTM C-136 [31,36,38]. The test results of these properties are presented in Table 7. The physical properties of the aggregate satisfied the ASTM standard specification for concrete production. 


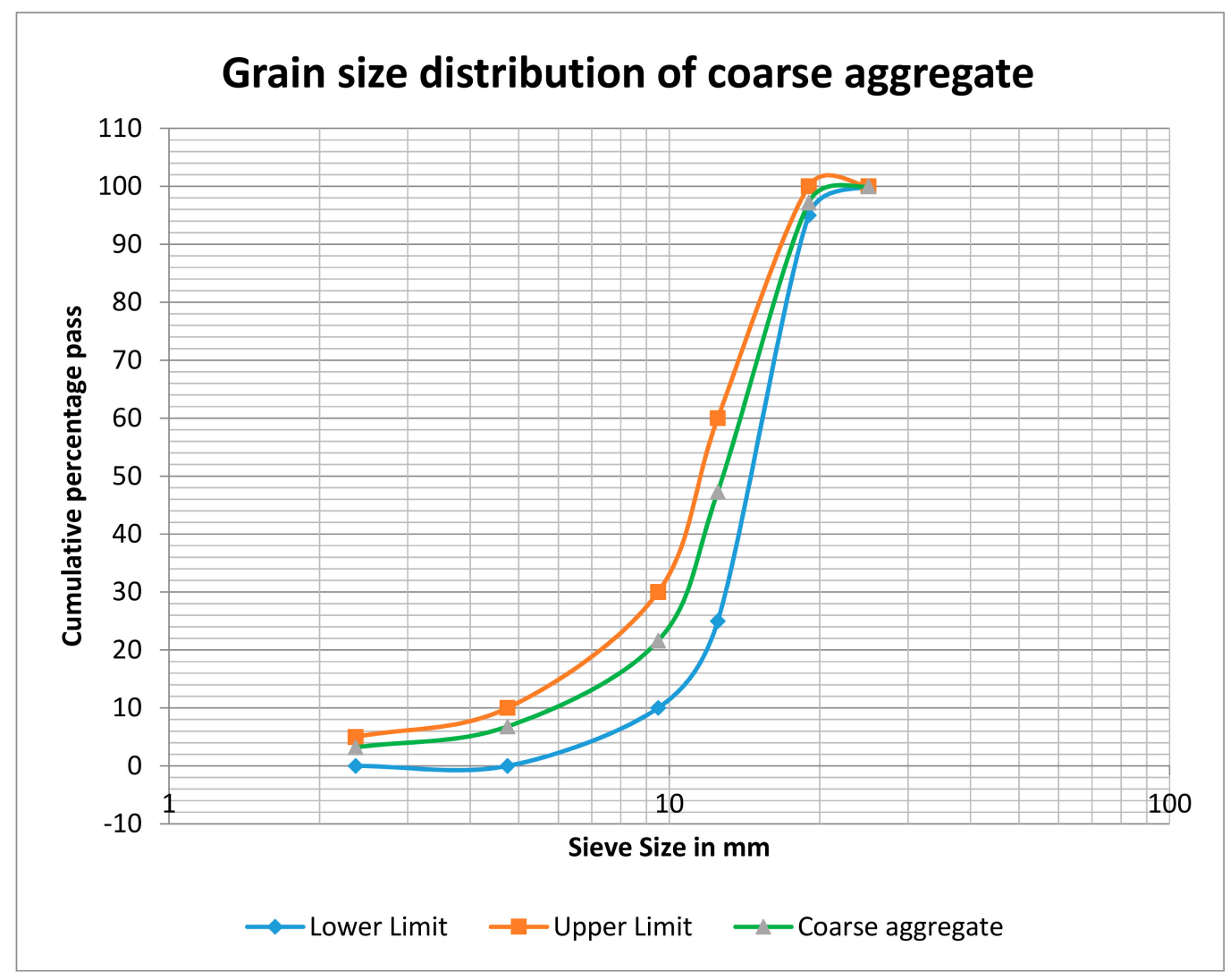

Figure 5. Gradation of coarse aggregate.

Table 7. Physical properties of coarse aggregate.

\begin{tabular}{cc}
\hline \multicolumn{2}{c}{ Coarse Aggregate Property } \\
\hline Bulk Specific Gravity & 2.65 \\
Apparent Specific Gravity & 2.73 \\
Water Absorption (\%) & 1.08 \\
Moisture Content $(\%)$ & 0.23 \\
\hline
\end{tabular}

\subsection{Cement}

Dangote ordinary Portland cement (OPC) with a grade of $42.5 \mathrm{R}$ was used in this study. The physical properties of Dangote OPC cement were determined as per ASTM standard specification(s). The physical properties of Dangote OPC, which include the standard consistency, setting time, fineness, and specific gravity, were determined using the standard specifications of ASTM C 187, ASTM C 191, ASTM C-184, and ASTM C 188, respectively [39-42]. The obtained result of the laboratory experiment on the cement fineness indicated that $100 \%$ passed the $150 \mu \mathrm{m}, 97.6 \%$ passed the $100 \mu \mathrm{m}$, and $92 \%$ and $78.2 \%$ passed the $90 \mu \mathrm{m}$ and $63 \mu \mathrm{m}$, respectively. The standard consistency, setting time, and specific gravity test results are indicated in Table 8 .

Table 8. Physical properties of cement.

\begin{tabular}{cc}
\hline Properties & Dangote OPC \\
\hline Specific Gravity & 3.13 \\
Standard Consistency (\%) & 32.4 \\
Initial Setting Time (min) & 80 \\
Final Setting Time (min) & 290 \\
\hline
\end{tabular}




\subsection{Water}

Tap water, which is used for drinking purposes, was used in this experimental work.

\subsection{Concrete Mix Design}

The American Concrete Institute (ACI) method of the mix design method was used in designing the concrete mixes. The trial mix was prepared for a concrete grade of C-25 compressive strength. A maximum aggregate size of $20 \mathrm{~mm}$ was used in the experiment. A water to cement ratio of 0.50 was used based on the maximum aggregate size and the concrete grade. By considering the workability of the concrete in line with the aggregate size and strength of the concrete, the amount of water required was determined following the ACI mix design table. Accordingly, the amount of water required for the mix is $185 \mathrm{~kg} / \mathrm{m}^{3}$. Based on the fineness modulus of the fine aggregate, the amount of the coarse aggregate was determined for the specified maximum aggregate size. The proportion of the concrete ingredients used in a unit cubic meter is indicated in Table 9, considering the associated physical properties of the materials.

Table 9. Proportion of the concrete constituents.

\begin{tabular}{cccccc}
\hline Constituents & Water $\left(\mathbf{k g} / \mathbf{m}^{\mathbf{3}}\right)$ & $\begin{array}{c}\text { Cement } \\
\left(\mathbf{k g} / \mathbf{m}^{\mathbf{3}}\right)\end{array}$ & $\begin{array}{c}\text { River Sand } \\
\left(\mathbf{k g} / \mathbf{m}^{3}\right)\end{array}$ & Scoria $\left(\mathbf{k g} / \mathbf{m}^{\mathbf{3}}\right)$ & $\begin{array}{c}\text { Coarse Aggregate } \\
\left(\mathbf{k g} / \mathbf{m}^{3}\right)\end{array}$ \\
\hline $100 \%$ RS + 0\% Scoria & 185 & 370 & 673.40 & 0.00 & 1087.80 \\
\hline $90 \%$ RS + 10\% Scoria & 185 & 370 & 606.06 & 67.34 & 1087.80 \\
\hline $75 \%$ RS + 25\% Scoria & 185 & 370 & 505.05 & 168.35 & 1087.80 \\
\hline $65 \%$ RS + 35\% Scoria & 185 & 370 & 437.71 & 235.69 & 1087.80 \\
\hline $50 \%$ RS + 50\% Scoria & 185 & 370 & 336.70 & 336.70 & 1087.80 \\
\hline
\end{tabular}

In this study, the fine aggregate used was a combination of scoria and river sand. Replacement of scoria was made with a percentage of $0 \%$ (control), $10 \%, 25 \%, 35 \%$, and $50 \%$ on a weight basis. The effects of the different levels of percentages were investigated on the workability and compressive strength of the concrete by measuring the slump height and compression machine, respectively.

\subsection{Concrete Tests}

Concrete tests were carried out to determine the properties of both fresh and hardened concrete. The slump cone method was used for the determination of the concrete consistency or workability of the fresh concrete using ASTM C143 [43]. A slump cone with $10 \mathrm{~cm}$ diameter at the top, $20 \mathrm{~cm}$ diameter at the bottom, and vertical height of $30 \mathrm{~cm}$ was used. The internal surface of the cone was cleaned and placed on a smooth horizontal surface. The cone was filled in three layers of equal height with concrete, and each layer was tamped 25 times with a $16 \mathrm{~mm}$ tamping rod. The slump value for each concrete mix was determined. The precision of the test result was checked as per the ASTM C143 to accept the test results. The observed slump values for each level of replacement are presented in Section 3.1.

The compressive strengths of the test specimens were determined using an automatic compression testing machine (UTC-4321) using ASTM C-39/39M [44]. Cubic steel molds of a $15 \mathrm{~cm}$ dimension were used to cast the concrete test specimens. Once the molds were firmly fixed, and their interior faces greased, the molds were filled in three layers each, with $5 \mathrm{~cm}$ being tapped 25 times manually with a steel rod. Three specimens were prepared for each test, and the specimens were stored in curing water tank for 7,28 , and 56 day periods at a room temperature of about $25^{\circ} \mathrm{C}$ [45]. The reliability in the precision of the measurement in the data set was checked by determining the standard deviation, and the error bars are indicated in the graphs presented in Figures 7-9. The standard deviations of the data sets varied from 0.14 to 0.478 , which is less than the acceptable precision of $1.4 \mathrm{MPa}$ applicable for a laboratory with in-test variation [46]. 


\section{Results and Discussion}

\subsection{Workability of Fresh Concrete}

The test result of the slump height observed is indicated in Table 10. The test result of the experimental work shows that the workability of the fresh concrete slightly increases as the amount of scoria replaced as fine aggregate increases. As the percentage of scoria increases, the fineness of the blended fine aggregate increases. The increase in the workability of the concrete is supposed to be due to the relative coarseness of the fine aggregate as a result of the replacement of scoria with the higher fineness of modulus as compared to the river sand (RS).

Table 10. Slump height of scoria replaced concrete.

\begin{tabular}{cc}
\hline Mix Designation & Slump Value $(\mathbf{m m})$ \\
\hline $100 \%$ RS $+0 \%$ Scoria & 32 \\
$90 \%$ RS $+10 \%$ Scoria & 33 \\
$75 \%$ RS $+25 \%$ Scoria & 35 \\
$65 \%$ RS $+35 \%$ Scoria & 36 \\
$50 \%$ RS $+50 \%$ Scoria & 38 \\
\hline
\end{tabular}

\subsection{Density of Hardened Concrete}

The density of the test sample at the age of the 56th day for the different levels or proportions of scoria replacement was determined, and the result indicated in Table 11. It can be seen from the table that the density of the concrete decreases as the percentage of scoria increases due to the lower unit weight of scoria. This finding confirms a research study made by Shannag et al. in 2014 [20]. The reduction in the density of concrete helps to decrease the self-weight of the concrete in the determination of the design dead of the concrete structural member to have reduced concrete cross-sectional dimension supporting the structural member and thus saves the amount of concrete volume relatively.

Table 11. Density of hardened concrete.

\begin{tabular}{cc}
\hline Mix Designation & Density, $\mathbf{k g} / \mathbf{m}^{\mathbf{3}}$ \\
\hline $100 \% \mathrm{RS}+0 \%$ Scoria & 2501.93 \\
$90 \% \mathrm{RS}+10 \%$ Scoria & 2482.68 \\
$75 \% \mathrm{RS}+25 \%$ Scoria & 2465.19 \\
$65 \% \mathrm{RS}+35 \%$ Scoria & 2458.62 \\
$50 \% \mathrm{RS}+50 \%$ Scoria & 2452.05 \\
\hline
\end{tabular}

The experimental test results show that the density of the hardened concrete decreases with increasing amounts of scoria percentage, which is expressed in a polynomial function with an equation of $\mathrm{Y}=0.018 \mathrm{X}^{2}-1.894 \mathrm{X}+2501.1$ as shown in Figure 6 , where $\mathrm{X}$ represents the percentage of scoria replacement. The density of the hardened concrete at any given percentage of scoria can be estimated using this equation. 


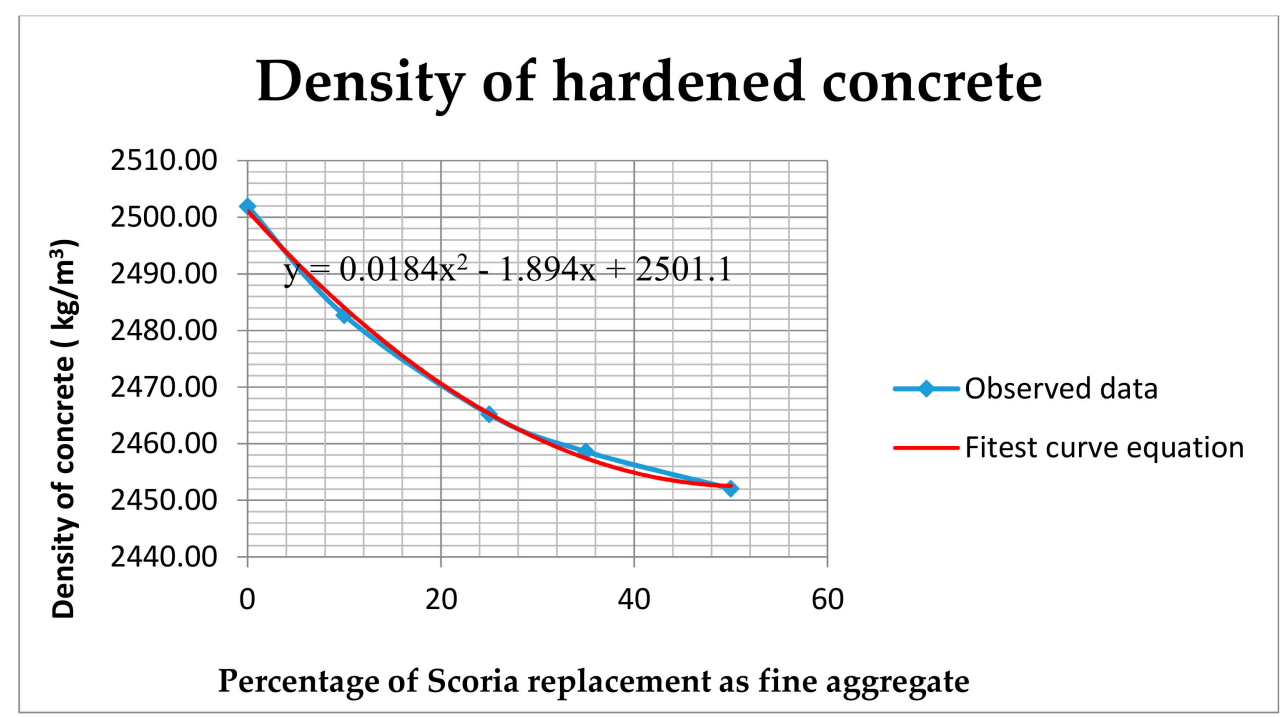

Figure 6. Density of hardened concrete as a function of scoria replacement.

\subsection{Compressive Strength}

The average compressive strength of scoria-replaced concrete of different curing ages is presented in Figures 7-9. The compressive strength test result of the experiment shows that there is an increase in the compressive strength at the curing ages of 7,28, and 56 days with an increase in the amount of the scoria used as fine aggregate as compared to that of the control sample. The average compressive strength of concrete for a scoria replacement of $10 \%, 25 \%, 35 \%$, and $50 \%$ increased by $1.879 \%, 4.212 \%$, $5.616 \%$, and $0.829 \%$, respectively, for the seven days age of curing compared to the control mix. For the age of the 28-day strength of the concrete, the levels of increments observed were $2.49 \%, 4.62 \%, 5.94 \%$, and $0.451 \%$ for the respective scoria replacement percentages. Almost the same amounts of increments were also observed for the 56-day concrete compared to the control.

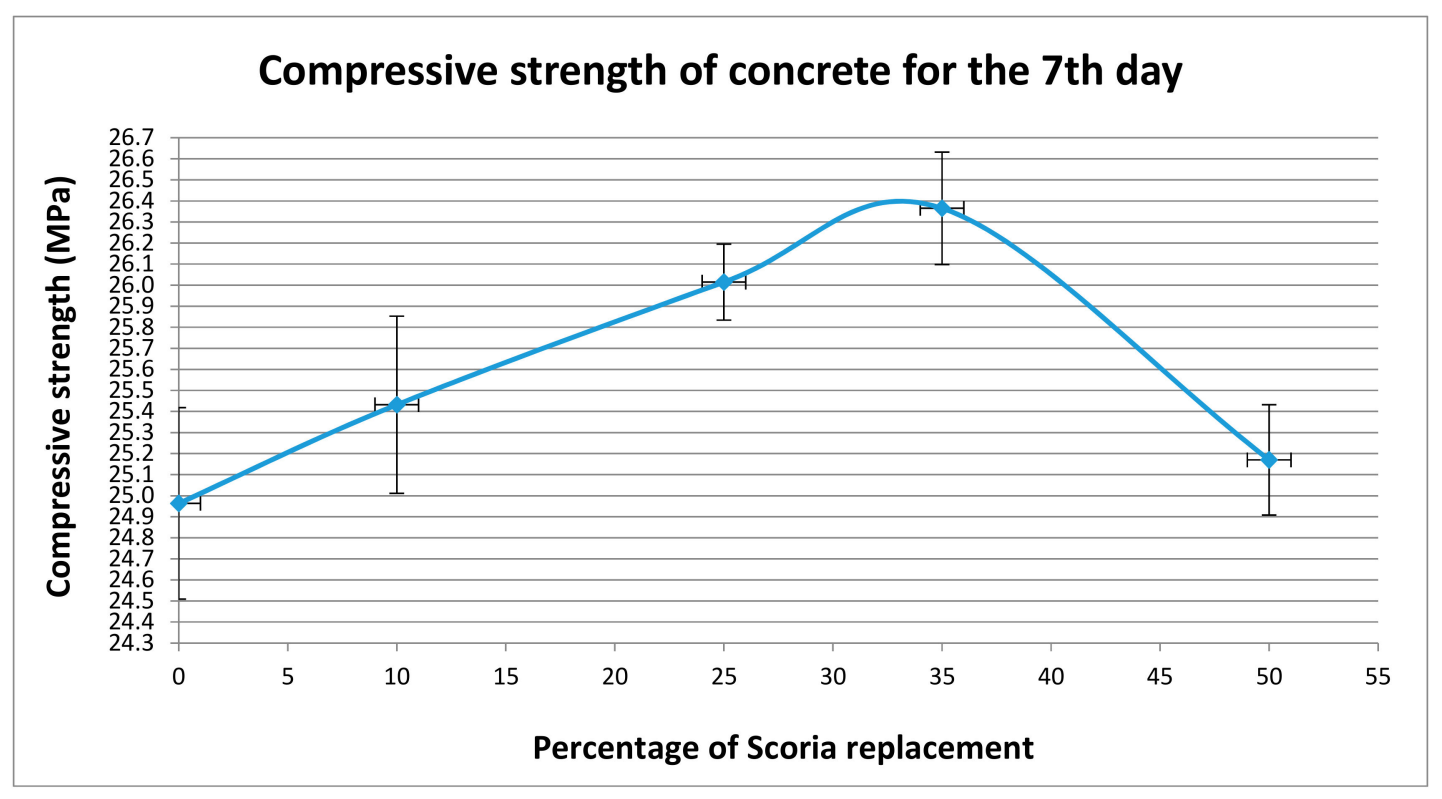

Figure 7. Compressive strength of seven-day age with an error bar. 


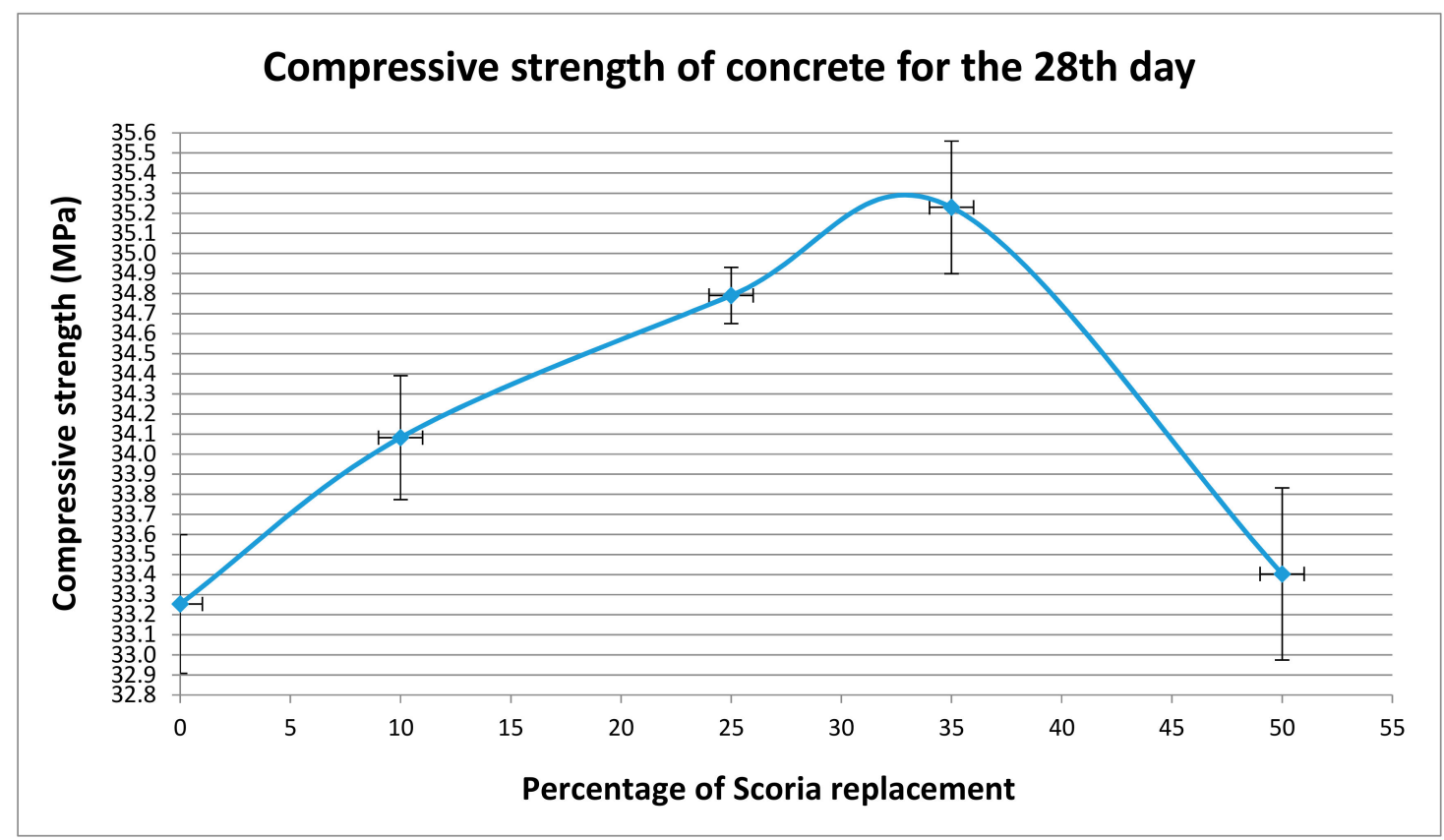

Figure 8. Compressive strength of 28-day age with error bar.

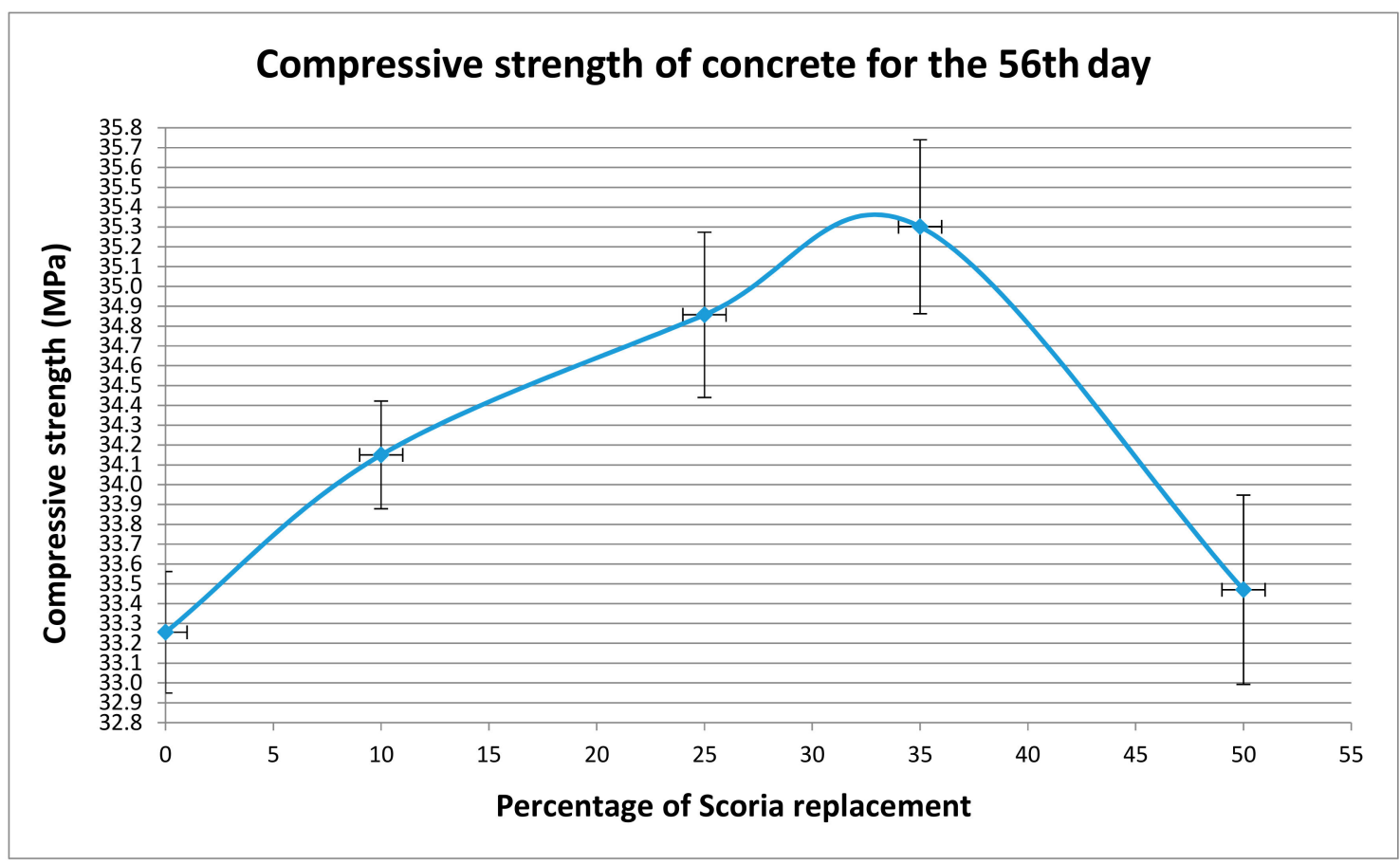

Figure 9. Compressive strength of 56-day age with error bar.

The enhancement in the properties of the concrete observed was due to the inherent physical properties of the scoria sample. The silt and clay content of scoria is smaller than the river sand while the water absorption capacity is almost similar. The decrease in the silt content of the blended concrete mixes helps the proper cement hydration processes to take place, favoring the compressive strength of the concrete to occur due to proper bondage between the aggregates. The blending of the finer river sand with the coarser scoria resulted in a well-graded particle size distribution, increasing the volume solid of the concrete and thereby increasing the strength of the concrete. 
The maximum compressive strength attained at a replacement of $35 \%$ of scoria. As the amount of scoria gets more and more, the amount of finer sand aggregates decreases, and thereby, the volume of solid decreases. Besides, the formation of the interaction of paste and aggregate also decreased due to the lowering of the filler or packing effect. As a result, the compressive strength of concrete declined beyond $35 \%$. However, the compressive strength with $50 \%$ replacement is still higher than that of the control sample due to the well-graded particle distribution of the blended fine aggregate as compared to that of the river sand. Generally, this experimental study shows that the scoria sample under consideration can replace the river sand up to $50 \%$ in order to produce concrete for the target mix design considered.

\section{Conclusions}

The findings of the study can be concluded as such: The evaluation of the properties of scoria showed that scoria is suitable to be used as a partial replacement of fine aggregate in the production of concrete. Scoria was found to have outstanding quality, especially with regards to its silt content compared to the river sand. Thus, the use of scoria as fine aggregate helps to save energy and cost of washing the river sand. It also produces improved concrete quality. The use of scoria in concrete production was found to increase the workability of the fresh concrete as compared to the control, favoring a better quality concrete. The compressive strength of the hardened concrete increased up to a 50\% replacement of scoria as a fine aggregate compared to the control concrete in which the river the sand was used. Thus, scoria can be used up to this level of replacement to produce the target design strength of concrete of C-25 grade. The river sand used in this study had a well-graded gradation of particle size distribution by using a 35\% replacement of the scoria sample, thus causing the hardened concrete to have maximum compressive strength. The density of the hardened concrete decreases as the ratio of scoria replacement increases due to its lesser specific gravity and induces the concrete to have a relatively decreased self-weight, and thus increases the strength to unit weight ratio or structural efficiency as compared to the control sample.

In general, scoria is suitable for use to produce concrete as a fine aggregate and partial replacement of river sand. Its local availability aids its choice as an alternative construction material. Its availability at a shorter distance compared to river sand around the central towns of Ethiopia helps to save energy and cost, and thus meets the strategy of green concrete production.

Author Contributions: Conceptualization, methodology, data collection and data analysis, validation, original draft writing and editing-G.K.W.; Supervision and editing-M.M.D., F.F.F., T.G.

Funding: This research was funded by the Deutsche Gesellschaft für Internationale Zusammenarbeit (GIZ), and the APC was funded by Jimma University Institute of Technology and Texas Tech University.

Acknowledgments: The authors are thankful to Texas Tech University, GIZ, and Jimma University Institute of Technology for their cooperation in providing the necessary support for carrying out this research study.

Conflicts of Interest: The authors declare no conflict of interest.

\section{References}

1. Hameed, M.S.; Sekar, A. Properties of green concrete containing quarry rock dust and marble sludge powder as fine aggregate. ARPN J. Eng. Appl. Sci. 2009, 4, 83-89.

2. Yang, L. Sustainability and innovative construction: Green building with concrete. J. Civ. Eng. Environ. 2012, 2,1-2.

3. Mengistu, T.; Haile, M. Industrial Minerals and Rocks Resource Potential of Ethiopia; Federal Democratic Republic of Ethiopia, Ministry of Mines, Geological Survey of Ethiopia: Addis Ababa, Ethiopia, 2003. Available online: http://etd.aau.edu.et/bitstream/handle/123456789/2268/Shewaferaw\%20Dinku\%20.pdf?sequence= 1\&isAllowed=y (accessed on 8 May 2017).

4. Shiferaw, B.; Abebe, D. The Use of Manufactured Sand in Concrete Production: Test Result and Cost Comparison. MSC Thesis, Faculty of Technology, Addis Ababa University, Addis Ababa, Ethiopia, 2006. 
5. Ararsa, W.; Emer, T.Q.; Abraham, A. Suitability of Ambo Sandstone Fine Aggregate as an Alternative River Sand Replacement in Normal Concrete Production. Am. J. Civ. Eng. Archit. 2018, 6, 140-146. [CrossRef]

6. Abebe, D. The Need for Standardization of Aggregates for Concrete Production in Ethiopian Construction Industry. Available online: https://scholarworks.wmich.edu/cgi/viewcontent.cgi?article=1089\&context= africancenter_icad_archive (accessed on 12 July 2018).

7. Ngugi, H.N.; Mutuku, R.N.; Gariy, Z.A. Effects of sand quality on compressive strength of concrete: A case study of Nairobi County and its Environs. J. Civ. Eng. 2014, 4, 255. [CrossRef]

8. Luo, F.J.; He, L.; Pan, Z.; Duan, W.H.; Zhao, X.L.; Collins, F. Effect of very fine particles on workability and strength of concrete made with dune sand. Construct. Build. Mater. 2013, 47, 131-137. [CrossRef]

9. Sabih, G.; Tarefder, R.A.; Jamil, S.M. Optimization of gradation and fineness modulus of naturally fine sands for improved performance as fine aggregate in concrete. Int. Conf. Sustain. Des. Eng. Constr. 2016, 145, 66-73. [CrossRef]

10. Olanitori, L. Mitigating the effect of clay content of sand on concrete strength. In Proceedings of the 31st Conference on Our World in Concrete and Structures, Singapore, 15-17 August 2006.

11. Savitha, R. Importance of Quality Assurance of Materials for Construction Work. Building Materials Research and Testing Division, National Building Research Organization, 2012. Available online: www.nbro.gov.lk/ images/content_image/publications/symposia/2010/importance_of_quality_assurance.pdf. (accessed on 10 August 2019).

12. Muller, H.S.; Haist, M.; Vogel, M. Assessment of the sustainability potential of concrete and concrete structures considering their environmental impact, performance and lifetime. Constr. Build. Mater. 2014, 67, 321-337. [CrossRef]

13. Azhagarsamy, S.; Sumaiya Fathima, A.M.; Thilagavathi, K. Effect of Quarry Dust on High Performance Concrete. Int. Res. J. Eng. Tech. 2017, 4, 1223-1226.

14. Mamta, K.; Rabbani, A. Use of Quarry Dust as fine aggregates by Partial Replacement of Sand in Concrete. Int. Res. J. Eng. Technol. 2017, 4, 851-853.

15. Safiuddin, M.; Raman, S.N.; Zain, M.F.M. Utilization of Quarry Waste Fine Aggregate in Concrete Mixtures. J. Appl. Sci. Res. 2007, 3, 202-208.

16. Sukesh, C.; Krishna, K.B.; Teja, P.S.L.S.; Rao, S.K. Partial replacement of sand with quarry dust in concrete. Int. J. Innov. Technol. Explor. Eng. 2013, 2, 254-258.

17. Patnaik, B.; Seshadri, S.; Rao, S.C. Strength and durability properties of copper slag admixed concrete. IJRET Int. J. Res. Eng. Technol. 2015. [CrossRef]

18. Saha, A.K.; Sarker, P.K. Compressive strength of mortar containing ferronickel slag as replacement of natural sand. Procedia Eng. 2017, 171, 689-694. [CrossRef]

19. Aho, I.; Uungwa, S. Engineering properties of scoria concrete as a construction material. Glob. J. Eng. Res. 2015, 14, 59-63. [CrossRef]

20. Shannag, M.; Charif, A.; Naser, S.; Faisal, F.; Karim, A. Structural Behavior of Lightweight Concrete Made with Scoria Aggregates and Mineral Admixtures. Int. J. Civ. Archit. Sci. Eng. 2014, 8, 105-109.

21. Tchamdjou, W.H.J.; Grigoletto, S.; Michel, F.; Courard, L.; Abidi, M.L.; Cherradi, T. An investigation on the use of coarse volcanic scoria as sand in Portland cement mortar. Case Stud. Constr. Mater. 2017, 7, 191-206. [CrossRef]

22. Cai, G.; Noguchi, T.; Degée, H.; Zhao, J.; Kitagaki, R. Volcano-related materials in concretes: A comprehensive review. Environ. Sci. Pollut. Res. 2016, 23, 7220-7243. [CrossRef] [PubMed]

23. Hossain, K.; Lachemi, M. Fresh, mechanical, and durability characteristics of self-consolidating concrete incorporating volcanic ash. J. Mater. Civ. Eng. 2009, 22, 651-657. [CrossRef]

24. Al-Swaidani, A.M.; Aliyan, S.D. Effect of adding scoria as cement replacement on durability-related properties. Int. J. Concr. Struct. Mater. 2015, 9, 241-254. [CrossRef]

25. Hossain, K.M.A. Blended cement and lightweight concrete using scoria: Mix design, strength, durability and heat insulation characteristics. Int. J. Phys. Sci. 2006, 1, 5-16.

26. Niguse, T.; Shiferaw, T. Scoria sand replacement in structural concrete. Zede J. 1984, 6, 27-32.

27. Bontempi, E. A new approach for evaluating the sustainability of raw materials substitution based on embodied energy and the $\mathrm{CO}_{2}$ footprint. J. Clean. Prod. 2017, 162, 162-169. [CrossRef] 
28. Kupwade, P.K.; DeWolf, C.; Chin, S.; Ochsendof, J.; Hajiah, A.E.; Al-Mimin, A.; Büyüköztürk, O. Impact of Embodied Energy on materials/buildings with partial replacement of ordinary Portland Cement (OPC) by natural Pozzolanic Volcanic Ash. J. Clean. Prod. 2018, 177, 547-554. [CrossRef]

29. Neville, A.; Brooks, J. Concrete Technology (Edition-2001 Standards); Addison Wesley Longman: Harlow, UK, 2001.

30. ASTMC33. Standard Specification for Concrete Aggregates; ASTM International: West Conshohocken, PA, USA, 2013.

31. ASTMC136. Standard Test Method for Sieve Analysis of Fine and Coarse Aggregates; ASTM International: West Conshohocken, PA, USA, 2014.

32. EBCS. Ethiopian Standard Specification of Building and Road Materials; EFDR, Ethiopian Federal Democratic Republic Addis Ababa: Addis Ababa, Ethiopia, 2002.

33. Zongjin, L. Advanced Concrete Technology; John Wiley \& Sons: Hoboken, NJ, USA, 2011.

34. ASTMC117. Standard Test Method for Materials Finer than $75 \mu \mathrm{m}$ Sieve in Mineral Aggregates by Washing; ASTM International: West Conshohocken, PA, USA, 2004.

35. ASTMC128-15. Standard Test Method for Relative Density (Specific Gravity) and Absorption of Fine Aggregate; ASTM International: West Conshohocken, PA, USA, 2015.

36. ASTMC29/C29M. Standard Test Method for Bulk Density ("Unit Weight") and Voids in Aggregate; ASTM International: West Conshohocken, PA, USA, 2001.

37. ASTMC618. Standard Specification for Coal Fly Ash and Raw or Calcined Natural Pozzolan for Use in Concrete; ASTM International: West Conshohocken, PA, USA, 2012.

38. ASTMC127-15. Standard Test Method for Relative Density (Specific Gravity) and Absorption of Coarse Aggregate; ASTM International: West Conshohocken, PA, USA, 2015.

39. ASTMC187-11. Standard Test Method for Normal Consistency of Hydraulic Cement; ASTM International: West Conshohocken, PA, USA, 2011.

40. ASTMC191-13. Standard Test Methods for Time of Setting of Hydraulic Cement by Vicat Needle; ASTM International: West Conshohocken, PA, USA, 2013.

41. ASTMC184. Standard Test Method for Fineness of Hydraulic Cement by the 150-Micrometer (No. 100) and 75-Micrometer (No. 200) Sieves; ASTM International: West Conshohocken, PA, USA, 1994.

42. ASTMC188-17. Standard Test Method for Density of Hydraulic Cement; ASTM International: West Conshohocken, PA, USA, 2017.

43. ASTMC143/C143M-15a. Standard Test Method for Slump of Hydraulic-Cement Concrete; ASTM International: West Conshohocken, PA, USA, 2015.

44. ASTMC39/39M. Standard Test Method for Compressive Strength of Cylindrical Concrete Specimens; ASTM International: West Conshohocken, PA, USA, 2016.

45. ASTMC192/C192M. Standard Practice for Making and Curing Concrete Test Specimens in the Laboratory; ASTM International: West Conshohocken, PA, USA, 2007.

46. ACI-214R-11. Guide to Evaluation of Strength Test Results of Concrete; ACI Committee: Framington Hills, MI, USA, 2011.

(C) 2019 by the authors. Licensee MDPI, Basel, Switzerland. This article is an open access article distributed under the terms and conditions of the Creative Commons Attribution (CC BY) license (http://creativecommons.org/licenses/by/4.0/). 